\title{
Fyrsta meðferð með tocilizumab við COVID-19 hérlendis
}

\section{- sjúkratilfelli}

\section{Aron Hjalti Björnsson ${ }^{1}$ Porbjörg Ólafsdóttir ${ }^{2}$ \\ Katrín María Pormar ${ }^{3}$ \\ Már Kristjánsson ${ }^{4}$ \\ Anna Sesselja Pórisdóttir ${ }^{4}$ \\ Björn Rúnar Lúovíksson ${ }^{5,6}$ \\ Sigurður Guð̃mundsson ${ }^{4,6}$ \\ Magnús Gottfreðsson ${ }^{4,6}$}

Höfundar eru öll læknar.

\begin{abstract}
${ }^{1}$ Lyflækningasviði Landspítala, ${ }^{2}$ röntgendeild, ${ }^{3}$ svæfinga- og gjörgæsludeild,

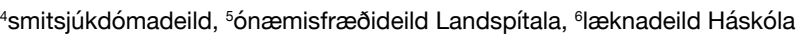
Íslands.
\end{abstract}

Fyrirspurnum svarar Aron Hjalti Björnsson, aron_hjalti@icloud.com

Höfundar fengu sampykki sjúklings fyrir pessari umfjöllun og birtingu.

\section{Inngangur}

Síðastliðna mánuði hefur heimsfaraldur með nýrri kórónuveiru, (Severe Acute Respiratory Syndrome Coronavirus-2, SARS-CoV-2) lagt tugi púsunda að velli og valdið gríðarlegum skaða. Sjúkdómurinn sem veiran veldur er kallaður kórónuveirusjúkdómur, eða COVID-19 á ensku (coronavirus disease 2019). SARS-CoV-2 er af flokki betakórónuveira (betacoronavirus). ${ }^{1}$ Meginsmitleið er um öndunarveg par sem veiran hefur innrás sína í pekjuvef meðal annars í gegnum ACE-2 viðtaka (angiotensin converting enzyme 2). ${ }^{2}$ Faraldurinn hófst í borginni Wuhan í Hubei-héraði í Kína síðla árs 2019 og hefur síðan breiðst hratt um heiminn. Eins og annars staðar hefur faraldurinn leikið almenning hér á landi grátt, auk verulegs efnahagslegs skaða fyrir íslenskt samfélag sem enn sér ekki fyrir endann á. Samhliða pessu hefur purft að umturna skipulagi og framkvæmd heilbrigðispjónustu í landinu. Pegar petta er skrifað hafa tæplega 1800 staðfest smit verið greind hérlendis, samkomubann er enn í gildi, auk annarra samfélagslegra takmarkana með víðtæk áhrif á starfsemi fyrirtækja og stofnana. Stofnuð hefur verið sérstök COVID-göngudeild á Landspítala sem hefur sinnt hátt í 1800 manns. Par af hafa nálægt 100 einstaklingar verið lagðir inn á spítalann, 13 farið í öndunarvél og 10 eru látin. Enn er mikil óvissa um bestu meðferð pessarar sýkingar og engin gagnreynd lyfjameðferð í boði, en margs konar klínískar prófanir í gangi víðs vegar um heiminn.

\section{Sjúkratilfelli}

Rétt rúmlega fimmtugur karlmaður sem hafði verið á ferðalagi erlendis veiktist með flensulíkum einkennum við komuna til lands-

\section{Á G R I P}

Rúmlega fimmtugur karlmaður sem hafði verið á ferðalagi erlendis veiktist við komuna til landsins með flensulíkum einkennum og greindist með COVID-19. Nokkrum dögum síðar versnandi honum af öndunarfæraeinkennum og lagðist inn á Landspítala. Hann reyndist vera súrefnisháđur og með útbreiddar íferðir í lungum. Eftir innlögn fékk hann versnandi öndunarbilun og var fluttur á gjörgæsludeild par sem hann var meðal annars meðhöndlaður með tocilizumab (IL-6 hemill). Hann sýndi batamerki í kjölfarið og purfti ekki að fara í öndunarvél.

ins og fór strax í sjálfskipaða sóttkví. Maðurinn var í yfirpyngd (BMI 32, líkamspyngdarstuðull, Body Mass Index) og með fyrri sögu um barnaastma og háprýsting sem var vel meðhöndlaður með lósartan, hýdróklórtíazíði og amlódipíni. Veikindin byrjuðu með vægum hita, hálssærindum, purrum hósta og hlustarverk. Daginn eftir komuna til landsins reyndist nefkoksstrok jákvætt fyrir SARS-CoV-2.

Í fyrstu var manninum fylgt eftir með reglulegum símtölum frá COVID-teymi Landspítala. Á 8. degi veikinda var hann kominn með sótthita, mikinn hósta, máttleysi og mæddist við gang. Næstu daga var hann að mestu hitalaus en með prálátan hósta, lystarleysi, ógleði, uppköst og niðurgang. Á 14. degi hækkaði hitinn og hann fann fyrir takverk og pyngslum fyrir brjósti, höfuðverk og prýstingi út í eyru. Einnig var hóstinn nú með uppgangi. Hann var lagður inn á smitsjúkdómadeild Landspítala til frekari rannsókna, greiningar og meðferðar.

Við komu á sjúkrahús var maðurinn veikindalegur, talmóður og með mikinn hósta. Hann var með $38^{\circ} \mathrm{C}$ hita og súrefnismettun var $88 \%$ á andrúmslofti en fór upp í 95\% á $4 \mathrm{~L} /$ mín súrefnis í nös. Öndunartíðni var 20-22/mínútur en önnur lífsmörk voru innan eðlilegra marka. Við lungnahlustun heyrðist fíngert brak yfir báðum lungum, mest neðarlega. Að öðru leyti var líkamsskoðun eðlileg. Blóðrannsókn (tafla I) sýndi hækkuð hvít blóðkorn, CRP (>200 mg/L) og ferritín (>2000 $\mu \mathrm{g} / \mathrm{L}$ ), lengdar blæðingarprufur og saltbrenglanir. Fengin var tölvusneiðmynd af brjóstholi sem sýndi dreifðar útlægar péttingar í öllum lungnablöðum; bæði hélubreytingar (ground glass) og íferðir í lungnablöðrum (alveolar consolidation) með loftberkjukortum (air bronchogram), sem voru taldar geta samrýmst COVID-19 lungnabólgu (mynd 1). Vegna möguleika á bakteríuyfirsýkingu var hafin meðferð með ceftríaxóni í æð og azitrómýsíni um munn. Jafnframt var hafin 5 daga meðferð með hýdroxýklórókíni um munn sem meðferð við COVID-19. Daginn eftir var sjúklingur með allt að $40^{\circ} \mathrm{C}$ hita, slæm hóstaköst og með mikla preytu og próttleysi. Hann var með versnandi hypoxíska öndunarbilun með súrefnismettun $88 \%$ á 5-6 L/ 


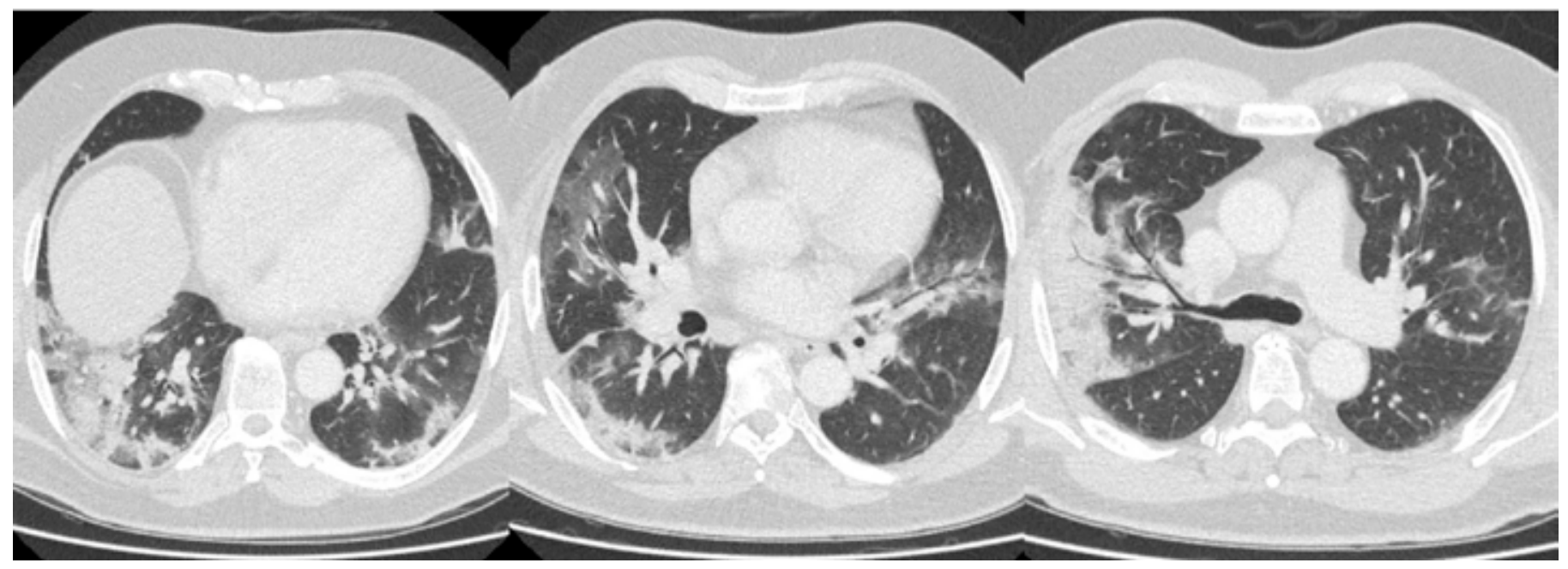

Mynd 1. Tölvusneiðmynd tekin við innlögn sjúklings. Útlægar hélubreytingar, lungnablöðruíferðir og loftberkjukort. Mynd úr sjúkraskrá.

mín súrefnis í hvíld, sem féll enn frekar við hóstaköst og áreynslu. Öndunartíðni var í kringum 20/mín en blóðprýstingur og hjartsláttartíðni voru innan eðlilegra marka. Vegna versnandi ástands, áhættupátta verri útkomu COVID-19-sjúkdóms og vaxandi bólgumyndunar í blóði (CRP og ferritín) var ákveðið að flytja sjúkling á gjörgæsludeild. Næstu klukkustundirnar hélt klínískt ástand áfram að versna og barkapræðing með innri öndunarvélarmeðferð var yfirvofandi. Hann var talinn vera með boðefnafár (cýtókín

Tafla I. Blóđrannsóknir fyrsta sólarhring innlagnar. D-dimer mældur seinna reyndist vera 6,14 (viðmið 0,5 mg/L).

\begin{tabular}{|c|c|c|c|}
\hline Blóðrannsókn & niðurstöður & viðmið & eining \\
\hline Hvít blóðkorn & 12,6 & $4-10,5$ & $\mathrm{x} 10^{9} / \mathrm{L}$ \\
\hline Hemóglóbín & 138 & $134-171$ & $g / L$ \\
\hline Neutrófílar & 10,9 & $1,9-7$ & $\times 10^{9} / L$ \\
\hline Eitilfrumur & 1 & $1-4$ & $\times 10^{9} / \mathrm{L}$ \\
\hline Mónócytar & 0,5 & $0,3-0,9$ & $\times 10^{9} / \mathrm{L}$ \\
\hline Eósínófílar & 0 & $<0,5$ & $\times 10^{9} / \mathrm{L}$ \\
\hline Basófílar & 0 & $<0,2$ & $\mathrm{x} 10^{9} / \mathrm{L}$ \\
\hline APTT & 53,5 & $29-44$ & sek \\
\hline PT & 16,5 & $12,5-15$ & sek \\
\hline INR & 1,1 & $0,8-1,1$ & \\
\hline Fíbrínógen & 7,3 & $1,5-4$ & $\mathrm{~g} / \mathrm{L}$ \\
\hline Natríum & 132 & $137-145$ & mmól/L \\
\hline Kalíum & 2,8 & $3,5-4,8$ & mmól/L \\
\hline Kreatínín & 81 & $60-100$ & mmól/L \\
\hline Gaukulsíunarhraði & $>90$ & $>60$ & $\mathrm{ml} / \mathrm{mín} / 1,73 \mathrm{~m}^{2}$ \\
\hline Ferritín & 2180 & $30-400$ & $\mu \mathrm{g} / \mathrm{L}$ \\
\hline CRP & 220 & $<10$ & $\mathrm{mg} / \mathrm{L}$ \\
\hline ALP & 55 & $35-105$ & $\mathrm{U} / \mathrm{L}$ \\
\hline ASAT & 24 & $<45$ & $\mathrm{U} / \mathrm{L}$ \\
\hline ALAT & 19 & $<70$ & $\mathrm{U} / \mathrm{L}$ \\
\hline Prókalsítónín & 0,16 & $<0,05$ & $\mu g / L$ \\
\hline
\end{tabular}

storm) og að höfðu samráði smitsjúkdóma- og gjörgæslulækna var ákveðið að hefja meðferð með tocilizumab (IL-6 hemill), $400 \mathrm{mg}$ í æð. Fyrir upphaf meðferðar voru bólguboðefni mæld (17 efna pakki). Par kom í ljós hækkun á IL-6 (22,04 pg/ml, viðmið <3,66 $\mathrm{pg} / \mathrm{ml})$, CD40L (5861 pg/ml, viðmið <4336 pg/ml) og MIP-3a (25 pg/ $\mathrm{ml}$, viðmið $<4 \mathrm{pg} / \mathrm{ml}$ ). Önnur bólguboðefni, par með talið IL-1 $\beta$ og TNF $\alpha$, voru eðlileg (tafla II). Á fyrstu klukkustund eftir lyfjagjöf fór líðan hans batnandi og hann varð hitalaus. Í kjölfarið fóru önnur lífsmörk batnandi og blóðprufur snérust til betri vegar. Á 20. degi var hann fluttur aftur á smitsjúkdómadeild. Sjúklingur purfti pá $5 \mathrm{~L} /$ mín súrefnis í nös til halda súrefnismettun yfir 93\%. Hann var inniliggjandi í 5 daga til viðbótar og á peim tíma jókst prek hans smám saman og lífsmörk og blóðprufur löguðust. Í kjölfar útskriftar var honum fylgt eftir af COVID-teymi Landspítala og hann var orðinn einkennalaus 34 dögum eftir að veikindi hófust.

\section{Umræða}

Á síðustu tveimur áratugum hafa orðið prír faraldrar sem nýjar kórónuveirur hafa valdið. COVID-19 faraldurinn er sá eini sem hefur orðið að heimsfaraldri, en hinir tveir voru SARS (Severe Acute Respiratory Syndrome) árin 2002-2004 og MERS (Middle Eastern Respiratory Syndrome) sem greindist fyrst 2012 og er enn að skjóta upp kollinum. ${ }^{2,3}$

Tafla II. Bólguboðefni við innlögn á gjörgæs/udeild. Einnig voru mæld IL-2, IL-4, IL-5, IL-10, IL-12, IL-12p70, IL-13, IL-15, IL17A, IL-17E, GM-CSF og IFN- $\gamma$ sem öll voru undir staðalkúrfu.

\begin{tabular}{|c|c|c|}
\hline Ónæmisrannsókn & Niðurstöður (pg/ml) & Við̆mið (pg/ml) \\
\hline IL-6 & 22,04 & $<3,66$ \\
\hline CD40L & 5861 & $<4336$ \\
\hline MIP-3a & 25 & $<4$ \\
\hline IL-1 $\beta$ & $0,74^{*}$ & $<0,34$ \\
\hline $\mathrm{TNF} \alpha$ & $6,75^{\star}$ & $<5,95$ \\
\hline
\end{tabular}

*Gildi undir staðalkúrfu 


\begin{tabular}{ll} 
Tafla III. Einkenni við upphaf veikinda. & $\%$ \\
\hline Hiti & $99^{1}$ \\
\hline Máttleysi & $70^{1}$ \\
\hline Purr hósti & $59^{1}$ \\
\hline Lystarleysi & $40^{1}$ \\
\hline Vöðvaverkir & $35^{1}$ \\
\hline Mæði & $31^{1}$ \\
\hline Bragð-/lyktarskynsbreytingar & $34^{2}$ \\
\hline
\end{tabular}

COVID-19 varð fyrst vart í kínversku borginni Wuhan í árslok 2019 pegar fjöldi fólks veiktist af lungnabólgu af óljósum toga. Síðan pá hefur sjúkdómurinn breiðst út og var skilgreindur sem heimsfaraldur af Alpjóðaheilbrigðisstofnuninni (WHO) pann 11. mars 2020. SARS-CoV-2 veiran er talin komast inn í frumur mannslíkamans með pví að bindast ACE-2 viðtaka á frumuhimnum. ${ }^{2}$ Pessi viðtaki er meðal annars tjáður í nýrum, hjarta, meltingarvegi, æðakerfi og pekjufrumum í lungnablöðrum (alveolar type 2 cells). ${ }^{2}$

Meðgöngutími er að meðaltali 4 dagar. ${ }^{6}$ Sjúkdómurinn byrjar með ósértækum einkennum eins og hita, hósta, máttleysi, mæði og bragð- eða lyktarskynstruflunum ${ }^{1,2,4,7}$ (tafla III). Yfirleitt eru pessi einkenni væg og ganga yfir. Í um 20\% tilfella fá einstaklingar alvarlegri einkenni og lungnabólgu, sem að meðaltali koma fram á fimmta degi veikinda. ${ }^{2,6}$ Eingöngu helmingur sjúklinga er með hita við innlögn en næstum $90 \%$ fá hita í sjúkrahúslegunni. ${ }^{6,7}$ Tölvusneiðmynd af lungum sýnir oftast hélubreytingar útlægt í báđum lungum. ${ }^{8}$

Blóðprufur í sjúklingum með alvarlega sýkingu sýna gjarnan eitilfrumnafæð, mikla hækkun á LDH, ferritíni, CRP og D-dimer, auk eðlilegs eða vægs hækkaðs prókalsítóníns (tafla IV). Greining á SARS-CoV-2-sýkingu byggir á kjarnsýrumögnun erfðaefnis veirunnar í háls- og nefkokstroki, en næmið er ekki pekkt og pví er mælst til að endurtaka sýnatöku ef einstaklingur reynist neikvæður en klínískur grunur er fyrir hendi. ${ }^{2}$ Hjá sjúklingum sem hafa lagst inn á Landspítala virðast einkenni frá meltingarvegum vera tiltölulega algeng, en fremur óalgeng samkvæmt erlendum uppgjörum $(3,8 \%)^{6}$

Meðferð við COVID-19 er fyrst og fremst stuðningsmeðferð. Fara ætti varlega með vökvagjöf í æð par sem SARS-CoV-2 getur skaðað hjartavöðvann auk pess sem leitast er við að halda neikvæðu vökvajafnvægi við meðferð á bráðu andnauðarheilkenni, ARDS (acute respiratory distress syndrome), sem er vel pekktur fylgikvilli COVID-19.,7,9 Par sem prókalsítónín er almennt ekki hækkað í COVID-19 er einkum stuðst við pað til að meta pörf á sýklalyfjum, en prókalsítónín er talið hækka sérstaklega í bakteríusýkingum. Samkvæmt meðferðarleiðbeiningum Landspítala ber að forðast notkun ytri öndunarvéla og háflæðis súrefnisgjafar vegna hættu á að framkalla loftborið smit, sem veldur aukinni sýkingarhættu fyrir starfsfólk og aðra sjúklinga. Í Kína voru 3,7\% smitaðra heilbrigðisstarfsfólk.10 Innlagðir sjúklingar á Landspítala hafa verið meðhöndlaðir með hýdroxýklórókíni samkvæmt ráðleggingum WHO, ${ }^{11}$ auk pess að azitrómýsíni er oft bætt við. Bæði pessi lyf

\begin{tabular}{l} 
Tafla IV. Rannsóknarniðurstöður tengdar verri horfum. ${ }^{11}$ \\
\hline$\downarrow$ Eitilfrumur \\
\hline$\uparrow$ LDH \\
\hline$\uparrow$ CRP \\
\hline$\uparrow \uparrow$ Ferritín \\
\hline$\uparrow$ PT \\
\hline$\uparrow$ Trópónín \\
Lifrarskaði \\
\hline Nýrnaskaði
\end{tabular}

geta valdið lengingu á QT-bili í leiðslukerfi hjartans og pví parf að taka hjartalínurit til eftirlits. Takmarkaðar rannsóknir eru til um virkni hýdroxýklórókíns en fram hafa komið rannsóknir sem sýna að lyfið hindri SARS-CoV-2 in vitro. ${ }^{12}$ Auk pess eru vísbendingar um að sé hýdroxýklórókín og azitrómýsín gefið saman geti pað flýtt fyrir að nefkoksstrok sjúklinga verði PCR-neikvætt. ${ }^{13}$ Forðast ætti notkun stera við meðhöndlun á COVID-lungnabólgum utan gjörgæslu. Rannsóknir á MERS og SARS sýndu engan ávinning við sterameðferð, en pvert á móti aukið magn veiru í blóði, lengt veirublæði (viremia) og verri klíníska endapunkta. ${ }^{14,15}$ Par að auki eykur sterameðferð dánartíðni í inflúensu. ${ }^{16}$

Um 15\% peirra sem leita á sjúkrahús verða bráðveikir með alvarlega öndunarbilun, lágprýsting eða fjölkerfabilun sem krefst gjörgæslumeðferðar. ${ }^{6}$ Versnun verður að meðaltali 7-12 dögum frá upphafi veikinda. ${ }^{2,6,7,10}$ Reynslan erlendis er að versnun beri oft hratt að með litlum fyrirboða. ${ }^{17}$ Pekkt er að sýktir einstaklingar geta fengið mikla súrefnispurrð án sértækra öndunarfæraeinkenna, sérstaklega aldraðir. ${ }^{18}$ Af pessum sökum er fylgst náið með súrefnismettun innlagðra og reynt að setja pá sem eru með váleg rannsóknargildi (tafla III) í sírita.

Sjúkdómurinn er frábrugðinn öðrum veirusjúkdómum að pví leyti að yfirsýkingar af völdum baktería eru ekki sterkur drifkraftur pessara alvarlegu veikinda. ${ }^{7}$ Hin brádu veikindi eru talin stafa af mikilli bólguvirkni eða boðefnafári. Heilkenni boðefnafárs stafar af ofræsingu á bólgusvari ónæmiskerfisins sem einkennist af óheftri framleiðslu boðefna, efnatoga og vaxtarpátta. ${ }^{19}$ Petta lýsir sér með viðvarandi hita, eitilfrumnafæð, hækkandi ferritíni, CRP og D-dímer og klínískri mynd sem getur samrýmst bráđu andnauðarheilkenni. ${ }^{2,19,20}$ Pessi gríðarlega bólgusvörun getur einnig valdið auknu gegndræpi æða og vanstjórnun á storkukerfi. ${ }^{20}$ Boðefnafári hefur verið lýst í kjölfar SARS-CoV og nú einnig SARS-CoV-2 sýkinga. ${ }^{21}$ Samhliða pessu geta sumir fengið rauðkornaátsheilkenni, tengt smiti (secondary haemophagocytic lymphohistiocytosis) sem einkennist af viðvarandi háum hita, hvítkornafæð, og hækkuðu ferritíni, auk pess sem lungnabólga (par með talið ARDS) sést í um pað bil helmingi tilfella. ${ }^{19,20}$

Fjölmargar leiðir hafa verið reyndar við meðhöndlun boðefnafárs, meðal annars með mótefnum gegn IL-1 $\beta$ og viðtökum IL-6. ${ }^{19,20}$ Báðar meðferðarleiðir hafa verið notaðar á Íslandi og víðar. Enn hafa ekki verið birtar niðurstöður samanburðarrannsókna varðandi virkni IL-6 hemla í COVID-19, aðeins tilfellaraðir og einstök sjúkratilfelli. ${ }^{22,23}$ IL-6 hemlar hafa pó gefist ágætlega í meðferð annarra sjúkdóma sem valda boðefnafári. ${ }^{20}$ pað er ekki að ástæðu- 
lausu að menn hafa gripið til slíkra tilraunameðferða hjá sjúklingum sem veikjast alvarlega af COVID-19, par sem nýlegar rannsóknir sýna að dánartíðni er 50-70\% meðal peirra sem leggjast inn á gjörgæsludeildir erlendis., ${ }^{2,7}$ Um $80 \%$ andláta eru á meðal einstaklinga eldri en 60 ára með undirliggjandi sjúkdóma á borð við háprýsting, hjartasjúkdóma, sykursýki, langvinna lungnasjúkdóma, krabbamein og langvinna nýrnabilun. ${ }^{2,7}$ Pessir sjúklingar purfa oft langa sjúkrahúslegu með tilheyrandi álagi á heilbrigðiskerfið.
Meðaltími veikinda að andláti eru um 2-8 vikur en meðaltími að bata hjá innlögðum sjúklingum er 6-8 vikur. ${ }^{2}$

Enn mun nokkur tími líða par til viðunandi árangur næst í meðferð einstaklinga með boðefnafár í kjölfar COVID-19. Hluti af peirri meðferð gæti orðið ónæmisbælandi lyfjameðferð sem myndi endurstilla bólgusvarið svo að hinn græðandi hluti ónæmissvarsins nái yfirhöndinni, líkt og hér virðist hafa gerst.

\section{Heimildir}

1. Wang D, Hu B, Hu C, Zhu F, Liu X, Zhang J, et al. Clinical Characteristics of 138 Hospitalized Patients with 2019 Novel Coronavirus-Infected Pneumonia in Wuhan, China. JAMA 2020; Feb 7.

2. Phua J, Weng L, Ling L, Egi M, Lim CM, Divatia JV, et al. Intensive care management of coronavirus disease 2019 (COVID-19): challenges and recommendations. Lancet Respir Med 2020; Apr 6.

3. World Health Organization. MERS situation update, January 2020.

4. Giacomelli A, Pezzati L, Conti F, Bernacchia D, Siano M, Oreni L, et al. Self-reported olfactory and taste disorders in SARS-CoV-2 patients: a cross-sectional study. Clin Infect Dis 2020; Mar 26.

5. Wu C, Chen X, Cai Y, Xia J, Zhou X, Xu S, et al. Risk Factors Associated with Acute Respiratory Distress Syndrome and Death in Patients with Coronavirus Disease 2019 Pneumonia in Wuhan, China. JAMA Intern Med 2020; Mar 13.

6. Guan W, Ni Z, Hu Y, Liang WH, Ou CQ, He JX, et al. Clinical Characteristics of Coronavirus Disease 2019 in China. N Engl J Med 2020; Feb 28.

7. Bhatraju PK, Ghassemieh BJ, Nichols M, Kim R, Jerome KR, Nalla AK, et al. Covid-19 in Critically Ill Patients in the Seattle Region - Case Series. N Engl J Med 2020; Mar 30.

8. Shi H, Han X, Jiang N, Cao Y, Alwalid O, Gu J, et al. Radiological findings from 81 patients with COVID-19 pneumonia in Wuhan, China: a descriptive study. Lancet Infect Dis 2020; Apr 20.
9. Keddissi JI, Youness HA, Jones KR, Kinasewitz GT. Fluid management in Acute Respiratory Distress Syndrome: A narrative review. Can J Respir Ther 2018; 55: 1-8.

10. Aylward, Bruce (WHO), Liang W (PRC). Report of the WHO-China Joint Mission on Coronavirus Disease 2019 (COVID-19). WHO-China Jt Mission Coronavirus Dis 2019. 2020.

11. World Health Organization. Clinical management of severe acute respiratory infection when novel coronavirus (2019-nCoV) infection is suspected: interim guidance, 28 January 2020. World Heal Organ.

12. Yao X, Ye F, Zhang M, Cui C, Huang B, Niu P, et al. In Vitro Antiviral Activity and Projection of Optimized Dosing Design of Hydroxychloroquine for the Treatment of Severe Acute Respiratory Syndrome Coronavirus 2 (SARS-CoV-2). Clin Infect Dis 2020; Mar 9.

13. Gautret P, Lagier J-C, Parola P, Hoang VT, Meddeb L, Mailhe $\mathrm{M}$, et al. Hydroxychloroquine and azithromycin as a treatment of COVID-19: results of an open-label nonrandomized clinical trial. Int J Antimicrob Agents 2020; Mar 20: 105949.

14. Arabi $\mathrm{YM}$, Mandourah $\mathrm{Y}, \mathrm{Al}$-Hameed $\mathrm{F}$, Sindi AA, Almekhlafi GA, Hussein MA, et al. Corticosteroid therapy for critically ill patients with middle east respiratory syndrome. Am J Respir Crit Care Med 2018; 197: 757-67.

15. Stockman LJ, Bellamy R, Garner P. SARS: Systematic review of treatment effects. PLoS Med 2006; 3: e343.
16. Lansbury L, Rodrigo C, Leonardi-Bee J, Nguyen-Van-Tam J, Lim WS. Corticosteroids as adjunctive therapy in the treatment of influenza. Cochrane Database Syst Rev 2019. 2: CD010406.

17. Rosenbaum L. Facing Covid-19 in Italy - Ethics, Logistics, and Therapeutics on the Epidemic's Front Line. N Engl J Med 2020; Mar 18

18. Xie J, Tong Z, Guan X, Du B, Qiu H, Slutsky AS. Critical care crisis and some recommendations during the COVID19 epidemic in China. Intensive Care Med 2020; Mar 2.

19. Mehta P, McAuley DF, Brown M, Sanchez E, Tattersall RS, Manson JJ. COVID-19: consider cytokine storm syndromes and immunosuppression. Lancet 2020; 395: 1033-4.

20. Tanaka T, Narazaki M, Kishimoto T. Immunotherapeutic implications of IL-6 blockade for cytokine storm. Immunotherapy 2016; 8: 959-70.

21. Zhou Y, Fu B, Zheng X, Wang D, Zhao C, qi Y, et al. Pathogenic $T$ cells and inflammatory monocytes incite inflammatory storm in severe COVID-19 patients. Natl Sci Rev 2020; Mar.

22. Zhang X, Song K, Tong F, Fei M, Guo H, Lu Z, et al. First case of COVID-19 in a patient with multiple myeloma successfully treated with tocilizumab. Blood Adv 2020; 4: 1307-10.

23. Luo P, Liu Y, Qiu L, Liu X, Liu D, Li J. Tocilizumab treatment in COVID-19: a single center experience. J Med Virol 2020; Apr 6.

\section{First case of COVID-19 treated with tocilizumab in Iceland}

\section{Aron Hjalti Björnsson ${ }^{1}$ Porbjörg Ólafsdóttir ${ }^{2}$ Katrín María Pormar ${ }^{3}$ Már Kristjánsson Anna Sesselja Pórisdóttir ${ }^{4}$ Björn Rúnar Lúóvíksson ${ }^{5,6}$ Sigurður Guðmundsson ${ }^{4,6}$ Magnús Gottfreðsson ${ }^{4,6}$}

A gentleman in his early fifties became ill with flu-like symptoms after vacationing abroad and was diagnosed with COVID-19 after returning to Iceland. A few days later he was admitted to the University Hospital, Landspitali, due to worsening respiratory symptoms and severe fatigue. A computed tomography scan of Ithe lungs showed diffuse bilateral consolidations and ground glass changes. He developed respiratory failure and was transferred to the intensive care unit where he received further treatment, including tocilizumab (IL-6 receptor inhibitor). He subsequently showed clinical improvement and did not require endotracheal intubation.

'Landspitali University Hospital, Department of Medicine, ${ }^{2}$ Landspitali University Hospital, Department of Radiology, ${ }^{3}$ Landspitali University Hospital, Department of Anesthesia and Intensive Care, ${ }^{4}$ Landspitali University Hospital, Department of Infectious Diseases, ${ }^{5}$ Landspitali University Hospital, department of immunology, ${ }^{6}$ University of Iceland, Faculty of Medicine.

Key words: COVID-19, SARS-CoV-2, IL-6, Tocilizumab, Cytokine storm, Coronavirus.

Correspondence: Aron Hjalti Björnsson, aronh@landspitali.is 